\title{
Enhancement of radiosensitivity in human glioblastoma cells by the DNA N-mustard alkylating agent BO-1051 through augmented and sustained DNA damage response
}

\author{
Pei-Ming Chu', Shih-Hwa Chiou ${ }^{2,3,4 \dagger}$, Tsann-Long Su ${ }^{5 \dagger}$, Yi-Jang Lee ${ }^{6 \dagger}$, Li-Hsin Chen ${ }^{3}$, Yi-Wei Chen ${ }^{4,7}$,
} Sang-Hue Yen ${ }^{7}$, Ming-Teh Chen ${ }^{8}$, Ming-Hsiung Chen ${ }^{8}$, Yang-Hsin Shih ${ }^{8}$, Pang-Hsien Tư ${ }^{5}$, Hsin-I Ma ${ }^{1 *}$

\begin{abstract}
Background: 1-\{4-[Bis(2-chloroethyl)amino]phenyl\}-3-[2-methyl-5-(4-methylacridin-9-ylamino)phenyl]urea (BO-1051) is an N-mustard DNA alkylating agent reported to exhibit antitumor activity. Here we further investigate the effects of this compound on radiation responses of human gliomas, which are notorious for the high resistance to radiotherapy.

Methods: The clonogenic assay was used to determine the $I_{50}$ and radiosensitivity of human glioma cell lines (U87MG, U251MG and GBM-3) following BO-1051. DNA histogram and propidium iodide-Annexin $V$ staining were used to determine the cell cycle distribution and the apoptosis, respectively. DNA damage and repair state were determined by $\gamma-\mathrm{H} 2 \mathrm{AX}$ foci, and mitotic catastrophe was measure using nuclear fragmentation. Xenograft tumors were measured with a caliper, and the survival rate was determined using Kaplan-Meier method.

Results: BO-1051 inhibited growth of human gliomas in a dose- and time-dependent manner. Using the dosage at $I C_{50}, B O-1051$ significantly enhanced radiosensitivity to different extents The sensitizer enhancement ratio was between 1.24 and 1.50 at $10 \%$ of survival fraction]. The radiosensitive $G_{2} / M$ population was raised by $B O-1051$, whereas apoptosis and mitotic catastrophe were not affected. $\gamma$-H2AX foci was greatly increased and sustained by combined BO-1051 and $\gamma$-rays, suggested that DNA damage or repair capacity was impaired during treatment. In vivo studies further demonstrated that BO-1051 enhanced the radiotherapeutic effects on GBM-3-beared xenograft tumors, by which the sensitizer enhancement ratio was 1.97. The survival rate of treated mice was also increased accordingly.
\end{abstract}

Conclusions: These results indicate that BO-1051 can effectively enhance glioma cell radiosensitivity in vitro and in vivo. It suggests that BO-1051 is a potent radiosensitizer for treating human glioma cells.

\section{Background}

Malignant gliomas account for approximately $30 \%$ of all intracranial tumors, and of them, glioblastoma multiforme $(\mathrm{GBM})$ is considered as the most frequent and aggressive type. Removal of GBM by surgical resection is usually not feasible due to the highly diffuse infiltrative

\footnotetext{
* Correspondence: uf004693@mail2000.com.tw

† Contributed equally

'Graduate Institutes of Life Sciences, National Defense Medical Center \& Department of Neurological Surgery, Tri-Service General Hospital, Taipei, Taiwan

Full list of author information is available at the end of the article
}

growth and recurrence rate [1]. A multicenter study has shown that addition of concurrent temozolomide (TMZ) to radical radiation therapy improves the survival in patients who suffered from GBM $[2,3]$. These studies have demonstrated an improvement for patients who received TMZ, compared to those who did not, in the median survival time and in the 2-year survival rate (14.6 vs. 12 months, $27 \%$ vs. $10 \%$, respectively). Unfortunately, the survival rate remains low using TMZ, and it prompts investigators to seek new and more effective chemotherapeutic agents for the treatment of malignant gliomas.

\section{Ciomed Central}


DNA alkylating agents are used widely for treatment of a variety of pediatric and adult cancers because the cytotoxic effects of these agents can directly modify DNA and cause DNA lesions [4]. However, the development of new alkylating $\mathrm{N}$-mustard agents is slow due to their low tumor specificity, high chemical reactivity and an induction of bone marrow toxicity $[5,6]$. To overcome these drawbacks, one strategy has been to design DNAdirected alkylating agents by linking the alkylating pharmacophore to the DNA-affinity molecules (e.g., DNA intercalating agents, DNA minor groove binder) $[7,8]$. In most cases, the DNA-directed alkylating agents have more selective, cytotoxic and potential than the corresponding untargeted derivatives [8-10]. Among these agents, the compound $\mathrm{BO}-0742$ exhibited significant cytotoxicity (107-fold higher) on human lymphoblastic leukemic cells than its parent analogue 3-(9-acridinylamino)-5-hydroxymethylaniline [9,11].

BO-0742 was found to have a potent therapeutic efficacy against human leukemia and solid tumor cell growth in vitro. Also, it has a good therapeutic index with leukemia being 10-40 times more sensitive than hematopoietic progenitors. Administration of BO-0742 at an optimal dose schedule, based on its pharmacokinetics, significantly suppressed the growth of xenograft tumors in mice bearing human breast and ovarian cancers. However, BO-0742's bioavailability is low because it has a narrow therapeutic window and is chemically unstable in mice (half-life $<25 \mathrm{~min}$ ) [12]. To improve the poor pharmacokinetics of BO-0742, we have recently synthesized a series of phenyl $\mathrm{N}$-mustard-9-anilinoacridine conjugates via a urea linker $[13,14]$. Of these agents, BO-1051 was found to be more chemically stable than BO-0742 in rat plasma (54.2 vs. $0.4 \mathrm{~h}$ ). BO-1051, an agent capable of inducing marked dose-dependent levels of DNA interstrand cross-linking (ICLs), revealed a broad spectrum of anti-cancer activities in vitro without cross-resistance to taxol or vinblastine. Due to BO-1051's hydrophobic ability, it can penetrate through the blood-brain barrier to brain cortex. BO-1051 has been shown to possess therapeutic efficacy in nude mice bearing human breast MX-1 tumors and human glioma in vivo [14]. Interestingly, we found that obvious tumor suppression was observed in mice and sustained over 70 days without relapse [14]. The results indicated that BO-1051 was more potent than cyclophosphamide with low toxicity to the host (15\% body-weight drop) suggesting that this agent is a promising candidate for preclinical studies.

Given that radiotherapy is considered to be the most effective adjuvant treatment with surgery, we tested if the therapeutic ability of BO-1051 could be translated into antitumor activity. In this study, we investigated the effects of BO-1051 on the radiosensitivity of a panel of three human glioma cell lines, and we found that treatment with BO-1051 at nanomolar concentrations sensitizes the glioma cells to radiation-induced cellular lethality. These data indicate that BO-1051 enhances tumor radiosensitivity in vitro and in vivo. Moreover, this sensitization correlates with its enhancement arrest in the radiosensitive cell cycle phase and the delayed dispersion of phosphorylated histone H2AX $(\gamma-\mathrm{H} 2 \mathrm{AX})$ foci, which suggests an inhibition of the repair to the DNA double-strand breaks (DBSs).

\section{Materials and Methods}

\section{Cell lines and treatment}

This research followed the tenets of the Declaration of Helsinki. All samples were obtained after patients provided informed consent. The study was approved by the Institutional Ethics Committee/Institutional Review Board of Tri-Service General Hospital. The commercial available U87MG, and U251MG glioma cell lines as well as primary GBM cell line (GBM-3), which was isolated from tumor sample obtained from patient undergoing surgery for a GBM (World Health Organizing Grade 4 astrocytoma), were grown as attached monolayers in $75-\mathrm{cm}^{2}$ flasks in DMEM media (Invitrogen) supplemented with glutamate $(5 \mathrm{mmol} / \mathrm{L})$ and $10 \%$ fetal bovine serum. Cells were incubated at the exponential growth phase in humidified $5 \% \mathrm{CO}_{2} / 95 \%$ air atmosphere at $37^{\circ} \mathrm{C}$. The GBM-3 cells used for the experiments had already undergone $>100$ passages. 1 - $\{4$-[bis $(2$-chloroethyl)amino]phenyl\}-3-[2-methyl-5- (4-methylacridin-9ylamino)phenyl]urea (BO-0151, Figure 1A) was dissolved in DMSO to a stock concentration of $5 \mathrm{mM}$ and stored at $-20^{\circ} \mathrm{C}$. Gamma radiation (ionizing irradiation) was delivered with a T-1000 Theratronic cobalt unit (Theratronic International, Inc., Ottawa, Canada) at a dose rate of $1.1 \mathrm{~Gy} / \mathrm{min}(\mathrm{SSD}=57.5 \mathrm{~cm})$.

\section{Assay of BO-1051 cytotoxicity}

For these studies, a specified number of single cells were seeded into a 25-T flask, and after $6 \mathrm{~h}$, to allow for cell attachment (but no division), the cells were treated with $0,50,100,200$ or $400 \mathrm{nM}$ BO-1051. At $0,6,12$ and $24 \mathrm{~h}$ after the BO-1051 addition, the BO-1051-containing medium was removed; the cells were washed with sterile PBS, and fresh media was added. After 10 to 14 days of incubation, colonies were fixed with methanol and stained with Giemsa. The number of colonies containing at least 50 cells was determined, and the plating efficiency (PE) and surviving fractions (SF) were calculated. The SF of cells exposed to $\times \mathrm{nM}$ BO-1051 for $\mathrm{t} h$ was calculated as [15]:

$$
\mathrm{SF}_{x n M, t h r}=\frac{\mathrm{PE}_{\mathrm{xnM}, \mathrm{thr}}}{\mathrm{PE}_{0 \mathrm{nM}, \mathrm{thr}}}
$$




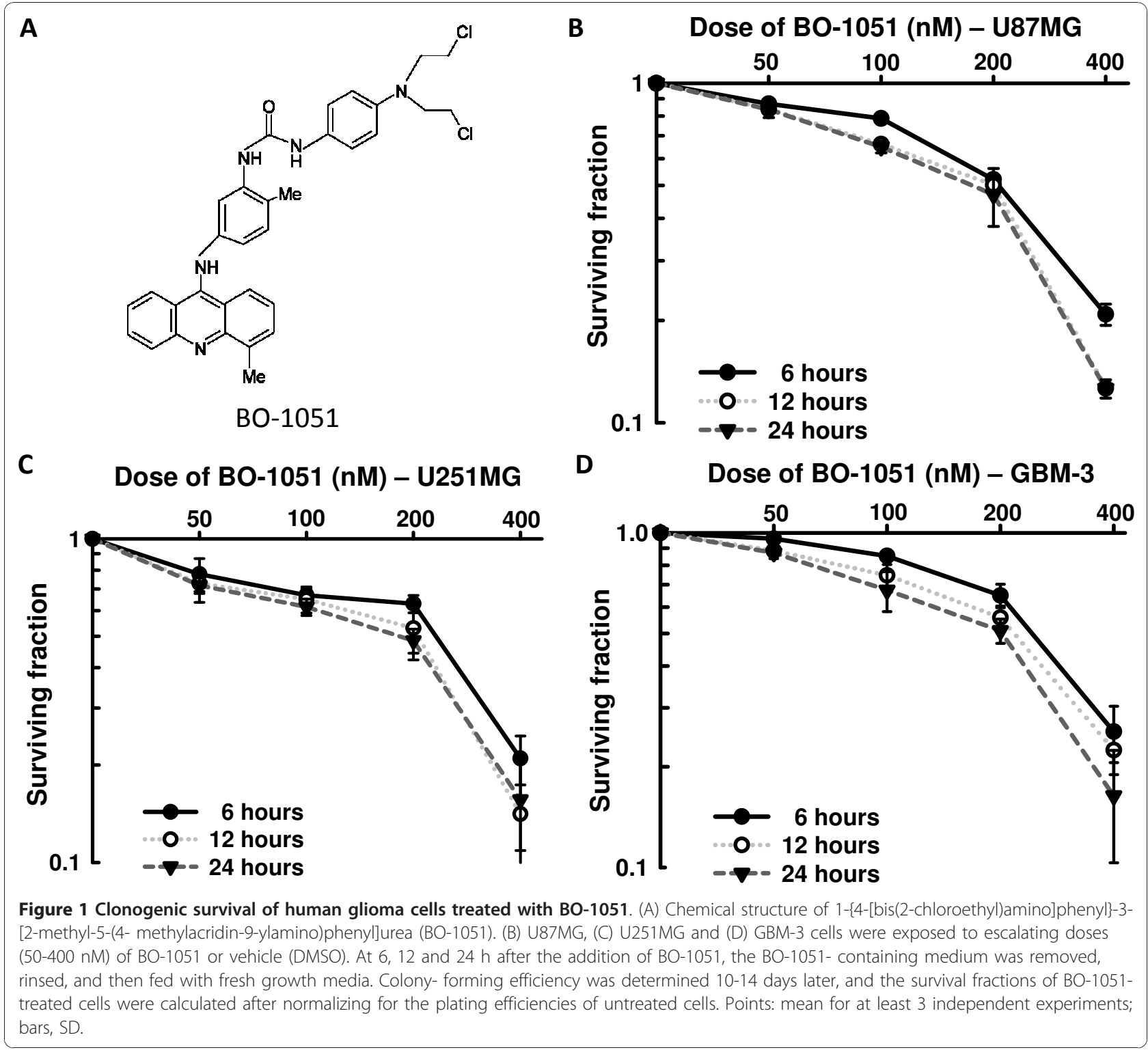

This protocol was used in an attempt to eliminate any effects of trypsinization on post-treatment or post-irradiation signaling/recovery processes [16-20]. Moreover, this protocol allows for the irradiation of single cells but not microcolonies, which eliminates the confounding parameter of multiplicity and its effects on the radiosensitivity.

\section{Combination of BO-1051 and irradiation}

After allowing the cells time to attach, the culture medium was then replaced with fresh medium that contained $200 \mathrm{nM}$ BO-1051, and the flasks were irradiated $24 \mathrm{~h}$ later. Immediately after irradiation, the growth media was aspirated, and fresh media was added. Colonies were stained with Giemsa 10 to 14 days after seeding. Survival curves were then generated after normalizing for the amount of BO-1051-induced cell death. The radiation SF of cells pretreated with $\times \mathrm{nM} \mathrm{BO}-1051$ was calculated as [15]:

$$
\mathrm{SF}_{\mathrm{xnM}, \mathrm{DG} y}=\frac{P E_{\mathrm{xnM}, \mathrm{DG} y}}{\mathrm{PE}_{\mathrm{xnM}, 0 G \mathrm{y}}}
$$

The combined therapeutic effects based on drug and ionizing irradiation was obtained by the survival fractions measured by separate treatment as reported previously [21]. The expected effect by two separate treatments was determined by the formula $\mathrm{SF}_{(\text {Drug })} \times \mathrm{SF}$ (Rad), which was compared to the observed survival fraction. 


\section{Cell-cycle analysis}

After treatment, cells were prepared for fluorescenceactivated cell sorting (FACS) to assess the relative distribution in the respective phases of the cell cycle. Cells were harvested $24 \mathrm{~h}$ after of treatment with BO-1051, pelleted by centrifugation, re-suspended in PBS, fixed in $70 \%$ ethanol and stored at $-20^{\circ} \mathrm{C}$. Immediately before flow cytometry, the cells were washed in cold PBS $\left(4^{\circ} \mathrm{C}\right)$, incubated in Ribonuclease A (Sigma) for $20 \mathrm{~min}$ at room temperature, labeled by adding an equal volume of propidium iodide solution $(100 \mu \mathrm{g} / \mathrm{ml})$ and incubated in the dark for $20 \mathrm{~min}$ at $4^{\circ} \mathrm{C}$. These samples were measured (20,000 events collected from each) in a FACSCalibur cytometer (BD FACS Caliber; Mountain View, CA). The data shown are for one experiment, but the results were reproduced and confirmed in at least three identical experiments.

\section{Annexin V-PI apoptosis assay}

To evaluate apoptosis as a mechanism of cell death, approximately $2 \times 10^{6}$ cells were plated in $100-\mathrm{mm}$ petri dishes. Cells were exposed to $200 \mathrm{nM}$ or higher concentration $(1.2 \mu \mathrm{M})$ of BO-1051 prior to irradiation and were stained at 24 and $48 \mathrm{~h}$ postirradiation (2 Gy). Both adherent and detached cells were collected, centrifuged, and double stained with Annexin V-FITC and propidium iodide (PI). Apoptotic cells were quantified with flow cytometry using a FACSCalibur cytometer (BD FACS Caliber, Mountain View, CA).

\section{Immunofluorescent staining for $\boldsymbol{\gamma}-\mathrm{H} 2 \mathrm{AX}$}

Cells were treated with or without BO-1051 for $24 \mathrm{~h}$ prior to irradiation (2 Gy) and fed with BO-1051-free medium, and the average number of foci per cell was measured beginning at $1 \mathrm{~h}$ after irradiation and followed thereafter for $24 \mathrm{~h}$. At specified times, the media were aspirated and cells were fixed in 1\% paraformaldehyde for $10 \mathrm{~min}$ at room temperature. Paraformaldehyde was aspirated, and the cells were treated with a $0.2 \%$ NP40/ PBS solution for $15 \mathrm{~min}$. Cells were then washed in PBS twice, and the anti- $\gamma \mathrm{H} 2 \mathrm{AX}$ antibody was added at a dilution of 1:500 in 1\% BSA and incubated overnight at $4^{\circ} \mathrm{C}$. Again, the cells were washed twice in PBS before incubating in the dark for $1 \mathrm{~h}$ with a FITC-labeled secondary antibody at a dilution of 1:100 in 1\% BSA. The secondary antibody solution was then aspirated, and the cells were washed twice in PBS. The cells were then incubated in the dark with PI $(1 \mu \mathrm{g} / \mathrm{ml})$ in PBS for $30 \mathrm{~min}$, washed twice, and coverslips were mounted with an anti-fade solution (Dako Corp.; Carpinteria, CA). Slides were examined with a confocal fluorescent microscope (Wetzlar, Germany). Images were captured by a Photometrics Sensys CCD camera (Roper Scientific; Tucson, AZ) and imported into the IP Labs image analysis software package (Scanalytics, Inc.; Fairfax, VA) running on a Macintosh G3 computer. For each treatment condition, $\gamma-\mathrm{H} 2 \mathrm{AX}$ foci were determined in at least 150 cells.

\section{In vivo tumor model}

Six-week-old female nude mice were used in these studies. Mice were caged in groups of five or less, and all animals were fed a diet of animal chow and water ad libitum. All procedures involving animals were performed in accordance with the institutional animal welfare guidelines of the Taipei Veterans General Hospital. Tumors were generated by injecting $5 \times 10^{6}$ GBM-3 cells subcutaneous (s.c.) into the right hind leg. Irradiation was performed using a T-1000 Theratronic cobalt unit (Theratronic International, Inc.; Ottawa, Canada) irradiator with animals restrained in a custom jig.

\section{Tumor growth delay assay}

The tumor re-growth delay assay measures the time required for a tumor to reach a given size post-treatment. When tumors grew to a mean volume of $\sim 150 \mathrm{~mm}^{3}$, mice were randomly assigned to one of four treatment groups: vehicle control (14 animals), BO-1051 (12 animals), 4 Gy irradiation (9 animals), or combined BO-1051 and radiation (8 animals). BO-1051 treatment was performed, which consisted of an intraperitoneal (i.p.) injection protocol of $50 \mathrm{mg} / \mathrm{kg}$ administered at 3-day intervals over a 6-day period (3 injections on days $0,3,6$; Q3D $\times 3$ ). For irradiation, unanesthetized animals were immobilized in a lead jig that allowed for the localized irradiation of the implanted tumors. Gamma radiation was delivered by a T-1000 Theratronic cobalt unit (Theratronic International, Inc.; Ottawa, Canada) at a dose rate of $1.1 \mathrm{~Gy} / \mathrm{min}(\mathrm{SSD}=$ $57.5 \mathrm{~cm}$ ). For the BO-1051-plus-radiation group, BO-1051 $(50 \mathrm{mg} / \mathrm{kg}$ ) was delivered via i.p. injection on days 0,3 , and 6, with day 0 being the day of randomization. Radiation (4 Gy) was delivered to animals restrained in a custom lead jig 24. h after the first injection of BO-1051 (day 1 after randomization). Tumor volume is a critical parameter in determining radiation-induced growth delay with smaller tumors appearing more radiosensitive. To ensure BO-1051-induced growth delay did not bias the results of the combination treatment (BO-1051 plus 4 Gy), it was important that the two irradiated groups (4 Gy and $\mathrm{BO}-$ 1051 plus 4 Gy) received radiation when the tumors were approximately the same size. To obtain tumor growth curves, perpendicular diameter measurements of each tumor were made every day with digital calipers, and the volumes were calculated using the formula for volume of an ellipsoid: $4 \Pi / 3 \times L / 2 \times W / 2 \times H / 2$, where $L=$ length, $W=$ width, and $H=$ height. The time for the tumor to grow again to ten times the initial volume (about $1500 \mathrm{~mm}^{3}$ ) was calculated for each animal. Absolute 
tumor growth delay was calculated as the number of days for the treated tumors to reach ten times the initial tumor volume minus the number of days for the control group to reach the same size.

The mean size of tumors receiving the combination treatment was compared to the mean size of tumors in mice from each of the other groups (receiving vehicle control, radiation alone, or BO-1051 alone). The analysis was done on day 42 after the treatment started because this was the last day that all animals were still alive. Time to treatment failure (TTF) was defined as the time from the initiation of treatment (experimental or control) to the time a tumor was severely necrotic or had reached a volume $>1500 \mathrm{~mm}^{3}$. Normalized tumor growth delay is defined as the time in days for tumors to reach 10 times the initial volume in mice treated with the combination of BO-1051 and radiation minus the time in days for the tumors to reach 10 times the initial volume in mice treated with BO-1051 only, which was 6.7 days (i.e., 16 minus 9.3 days).

\section{Statistical analysis}

The results are reported as mean \pm SD. Statistical analysis was performed using a Student's t-test, one-way ANOVA test or two-way ANOVA test followed by Tukey's test, as appropriate. A $P<0.05$ was considered to be statistically significant.

\section{Results}

Determination of the cytotoxicity of BO-1051 on different human glioma cell lines

To determine the effects of BO-1051 on glioma cell cytotoxicity by clonogenic survival, MTT assay was performed in a panel of 3 human malignant glioma cell lines (U87MG, U251MG and GBM-3). The IC 50 (concentration resulting in cell viability of $50 \%$ of control) values of BO-1051 for U87MG, U251MG and GBM-3 cells were $2.7,2.5$ and $1.5 \mu \mathrm{M}$, respectively. However, the clonogenic survival analysis showed little or no colony formation for $24 \mathrm{~h}$ post-exposure to the concentrations of $\mathrm{BO}-1051>400 \mathrm{nM}$. We found that the appropriate dosage range of $\mathrm{BO}-1051$ for colony formation in these glioma cell lines was between 50 and $400 \mathrm{nM}$. The cytotoxicity of U87MG, U251MG and GBM-3 cells were significantly influenced by BO-1051 in a time-dependent and dose-dependent manner. The 24-h treatment of $200 \mathrm{nM}$ BO-1051 resulted in SFs of $0.470 \pm 0.091,0.485$ \pm 0.041 and $0.510 \pm 0.042$ for U87MG, U251MG, and GBM-3, respectively (Figure 1). Because approximately $50 \%$ of survival fractions were reached using $200 \mathrm{nM}$ BO-1051 treatments on each glioma cells at $24 \mathrm{~h}$, we chose this dose for the following experiments.
Enhancement of radiosensitivity in glioma cells by BO-1051 To investigate if BO-1051 enhances the cellular sensitivity to ionizing radiation, the glioma cells were exposed to $\mathrm{BO}-1051$ for $24 \mathrm{~h}$ before irradiation and subjected to the clonogenic assay. The results showed that the SFs at different radiation dosages were apparently reduced in U87MG, U251MG and GBM-3 cells after they were exposed to BO-1051 (Figure. 2A-C). SFs after 2 Gy of BO-1051-pretreated cells were significantly lower than those of untreated cells (Figure 2D). Besides, the SERs were 1.50 for U87MG, 1.24 for U251MG and 1.31 for GBM-3 at a $10 \%$ cell survival (0.1). At $50 \%$ cell survival (0.5), the SERs were 1.87 for U87MG, 1.83 for U251MG and 1.68 for GBM-3 (Figure 2A-C, and 2E). As a result, the radiation survival curves obtained by the clonogenic assay showed that BO-1051 pretreatment sensitized human glioma cells to the ionizing radiation. Besides, Table 1 summarizes the relative reduction in SFs and compares them with a virtual value, expected for each of the combination of BO-1051 and irradiation dose. The actual SF measured for combinations is smaller than that expected on the basis of the treatment effects of each modality separately. It indicates a significant synergistic interaction in all three glioma cells.

\section{Induction of a $G_{2} / M$ phase arrest in glioma cells exposed to BO-1051}

Given that radiosensitivity is distinct in different phases of the cell cycle, we tested the cell cycle distribution in BO-1051 treated glioma cells $[22,23]$. Cells were treated with BO-1051 for $24 \mathrm{~h}$ and then subjected to flow cytometric analysis. As illustrated in the DNA histograms, BO-1051 treatment significantly disturbed the cell cycle progression and showed a dramatic increase in $G_{2} / M$ phase populations in U87MG cells compared with the untreated controls (Figure 3A). Quantitative analysis of the cell-cycle distribution at $24 \mathrm{~h}$ post-exposure to BO-1051 at different concentrations from $200 \mathrm{nM}$ to $1200 \mathrm{nM}$ is shown in Figure 3B-D, which shows that $G_{2} / M$ phase arrest was caused by pre-treatment with BO-1051 in a dose-dependent manner for all 3 glioma cells (Figure 3A-D). Because the $\mathrm{G}_{2} / \mathrm{M}$ phase is known as the cell cycle's most radiosensitive phase [22,23], it may in part account for the effects of BO-1051 on the enhancement of radiosensitivity of glioma cell line.

\section{Enhancement of radiosensitivity by BO-1051 treatment is not caused by apoptosis or mitotic catastrophes in glioma cells}

We next investigated whether BO-1051 enhanced radiation sensitivity of glioma cells was associated with increase of apoptosis. Cells were exposed to a range of 
A

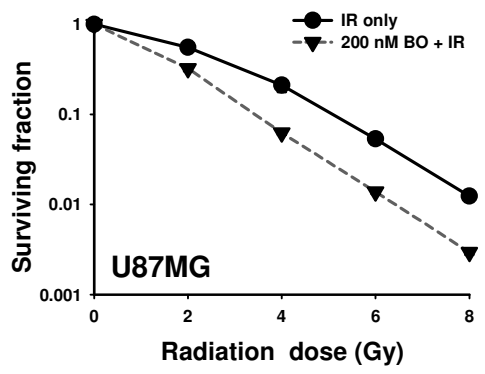

B

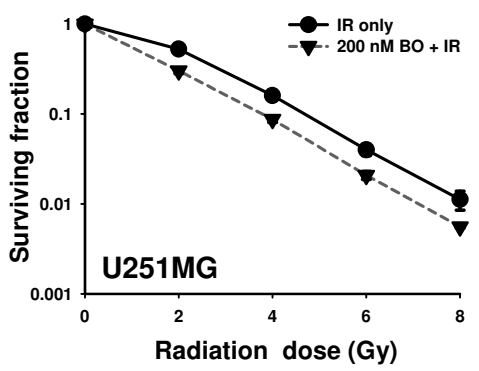

C

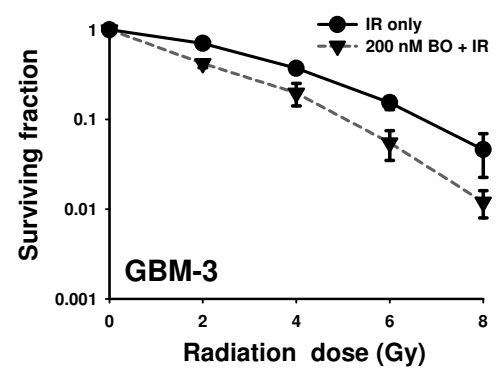

D

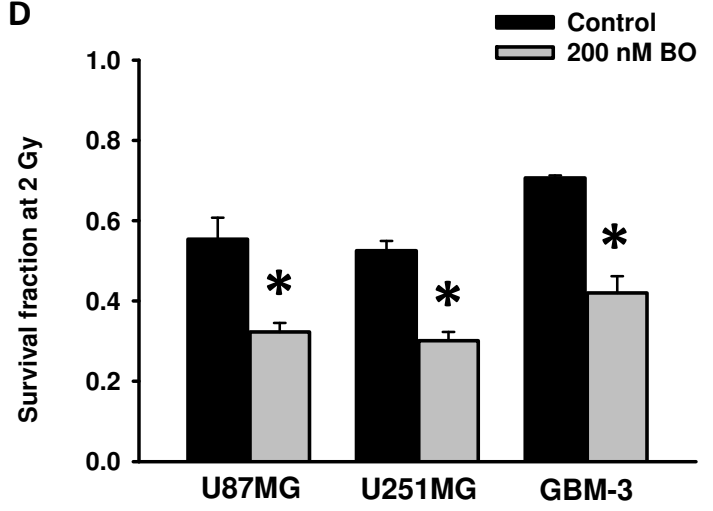

E

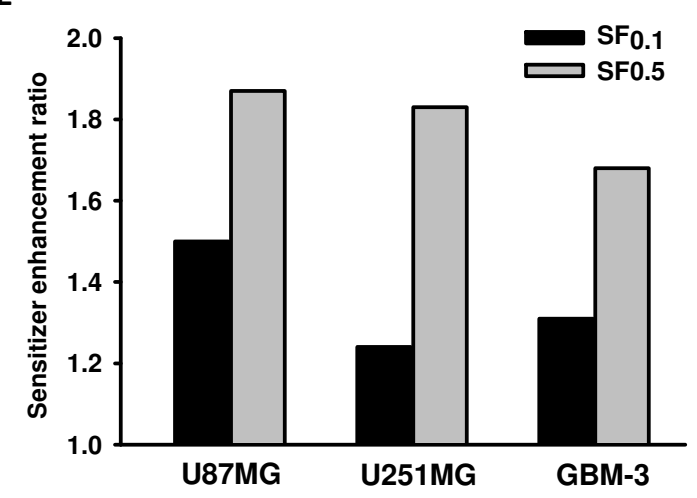

Figure 2 The effect of BO-1051 on tumor cell radiosensitivity. Cultures of (A) U87MG, (B) U251MG and (C) GBM-3 cells were exposed to 200 nM of BO-1051 or DMSO (IR only) for $24 \mathrm{~h}$ and irradiated with graded doses of $\gamma$-rays, rinsed, and fed with fresh growth media. Colony-forming efficiency was determined 10-14 days later, and survival curves were generated after normalizing for cell killing by BO-1051 alone. Points: mean survival fraction from at least 3 independent experiments; bars: SD. (D) The survival fraction after $2 \mathrm{~Gy}\left(\mathrm{SF}_{2}\right)$, corrected for independent cytotoxic effect of BO-1051, of human glioma cells treated with $200 \mathrm{nM}$ of BO-1051 or control (DMSO) for $24 \mathrm{~h}$ pre-radiation was measured. Values are the mean survival fraction \pm SD of at least 3 independent experiments. ${ }^{*} p<0.05$. (E) Sensitizer enhancement ratios (SER) of human glioma cells. SERs were calculated at $10 \%$ or $50 \%$ cell survival $(0.1$ or 0.5$)$ by dividing the dose of radiation from the radiation-only surviving curve with the corresponding dose from the BO- 1051 plus radiation curve.

BO-1051 concentrations (from 200 to $1200 \mathrm{nM}$ ) for $24 \mathrm{~h}$, and then were irradiated with 2 Gy of $\gamma$-rays. The Annexin V/PI staining was then determined with FACS analysis. Cells treated with either $200 \mathrm{nM}$ of BO-1051 alone or combined with irradiation exhibited less than

Table 1 Relative reduction in surviving fraction of three glioma cells due to combination of irradiation and BO1051 treatment

\begin{tabular}{cccc}
\hline \multirow{2}{*}{ Irradiation dose (Gy) } & \multicolumn{3}{c}{ Relative reduction (\%) } \\
\cline { 2 - 4 } & U87MG & U251MG & GBM-3 \\
\hline 2 & 41.7 & 42.6 & 40.6 \\
\hline 4 & 70.4 & 45.6 & 47.0 \\
\hline 6 & 74.2 & 47.9 & 64.3 \\
\hline 8 & 76.3 & 50.0 & 73.9
\end{tabular}

Percentage relative reduction of the observed surviving fraction (SF) compared to the expected SF (calculated on the basis of combing individual treatment component, each with respective SF value).
$5 \%$ of apoptosis (Figure 4). Moreover, treatment with 1200 nM BO-1051 significantly induced approximately $20 \%$ of apoptosis in all 3 cell lines, but the combined protocol did not show obvious enhancement on the proportion of apoptotic cell deaths (Figure 4). An increase in radiosensitivity may be caused by radiation-induced mitotic catastrophes. Nevertheless, no significant mitotic catastrophes were detected in glioma cells treated with both BO-1051 and irradiation up to $72 \mathrm{~h}$ (unpublished data). These data indicate that the BO-1051-mediated increase in radiosensitivity is not due to the apoptosis and mitotic catastrophes.

\section{BO-1051 combined with $\gamma$-rays causes prolonged DNA} damage response in glioma cells

DNA damage is the most important biological effects caused by ionizing radiation. It has been reported that the nuclear foci of $\gamma-\mathrm{H} 2 \mathrm{AX}$ is one of the canonical 


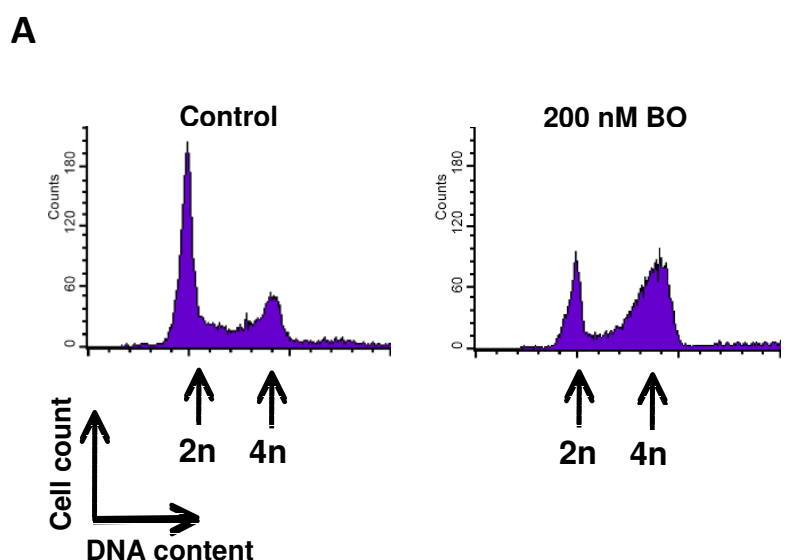

\section{U251MG}

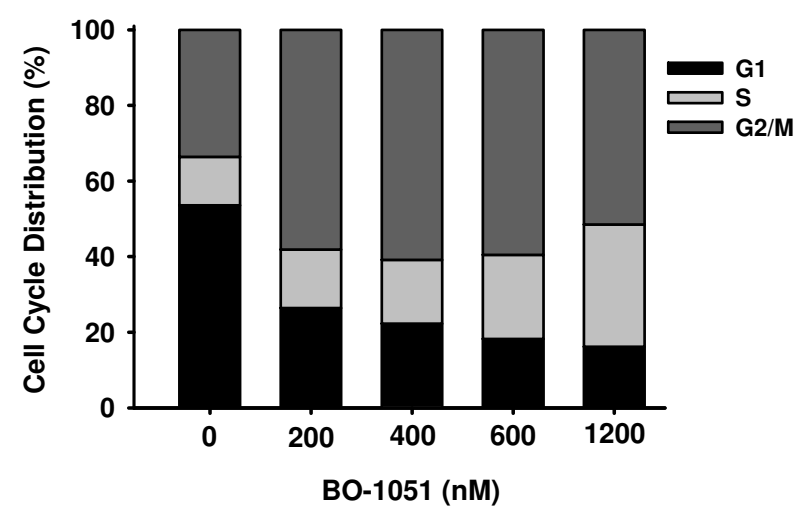

B U87MG

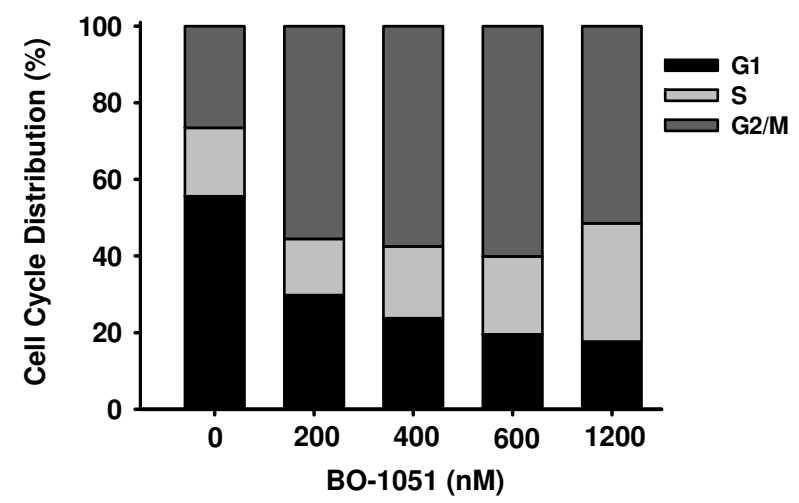

D GBM-3

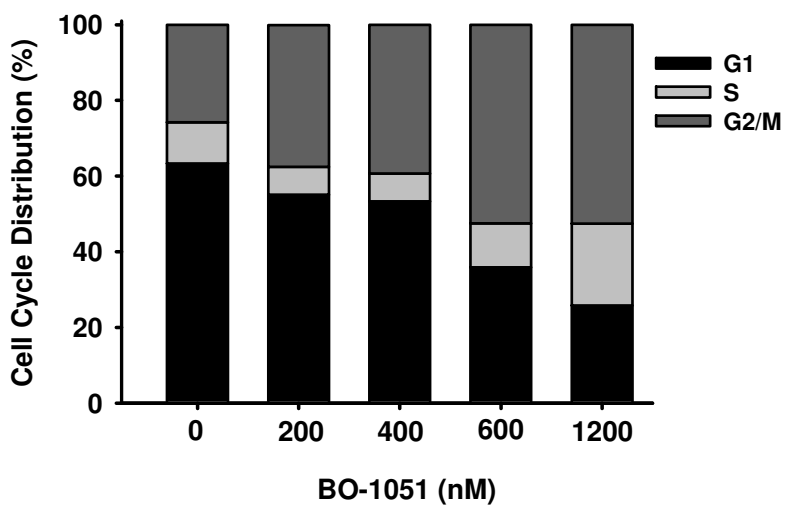

Figure 3 Effect of BO-1051 on cell cycle profile in human glioma cells. Cultures were exposed to BO-1051 for $24 \mathrm{~h}$ before collection and FACS analysis of the propidium iodide-stained cells. (A) The DNA histograms depict cell cycle phase distributions of U87MG 24 h post-treatment. Cells in exponential growth were sham treated (left panel), treated with BO-1051 (200 nM, right panel) and then harvested $24 \mathrm{~h}$ later. (B-D) Cell cycle distributions of a panel of 3 human glioma cell lines (U87MG, U251MG and GBM-3) were exposed to the designated concentrations of BO1051 for 24 h. Data displayed by the DNA content profiles were analyzed, and the cell cycle phase information is represented graphically.

markers for evaluating the level of DNA damage [24]. To investigate if BO-1051 can affect the extent of DNA damage by $\gamma$-rays, the formation of $\gamma$-H2AX foci in cell nuclei was determined. Cells were treated with or without BO-1051 for $24 \mathrm{~h}$ prior to irradiation (2 Gy) and fed with BO-1051-free medium, and the average number of foci per cell was measured beginning at $1 \mathrm{~h}$ after irradiation and followed thereafter for $24 \mathrm{~h}$. The results showed that exposure of glioma cells to either BO-1051 or irradiation (2 Gy) resulted in a significant increase of $\gamma$-H2AX foci at $1 \mathrm{~h}$ that was sustained for $6 \mathrm{~h}$, and then the $\gamma$-H2AX foci declined to almost basal level at least $24 \mathrm{~h}$ after irradiation or drug removal (Figure 5A and $5 \mathrm{~B})$. The combined protocol resulted in a greater number of $\gamma$-H2AX foci than either of the individual treatments at 1 or $6 \mathrm{~h}$. However, the number of residual $\gamma$-H2AX foci per cell $24 \mathrm{~h}$ post-irradiation was greater in BO-1051 plus irradiation (19.9 \pm 2.5 per cell) compared with the number of foci in cells treated with either irradiation or BO-1051 alone $(7.9 \pm 2.8$ and 11.2 \pm 1.9 per cell, respectively) (Figure $5 \mathrm{~A}$ and $5 \mathrm{~B}$ ). Furthermore, the frequency of $\gamma-\mathrm{H} 2 \mathrm{AX}$ foci distribution at $24 \mathrm{~h}$ post-irradiation showed that the percentage of $>30$ foci of $\gamma$-H2AX was higher than additive in BO-1051 plus irradiation $(24.9 \%)$ compared with the percentage of foci in cells treated with either irradiation or BO-1051 alone ( $0.3 \%$ and $12.0 \%$, respectively). These results suggest that BO-1051 produces supra-additive and prolonged effects of irradiation on glioma cells.

BO-1051 delays the growth of xenograft gliomas exposed to irradiation

To determine if the enhanced radiosensitivity of BO-1051 treated glioma cells could be translated into an in vivo tumor model, a tumor growth delay assay using GBM-3 cells grown s.c. in the hind leg of nude mice 


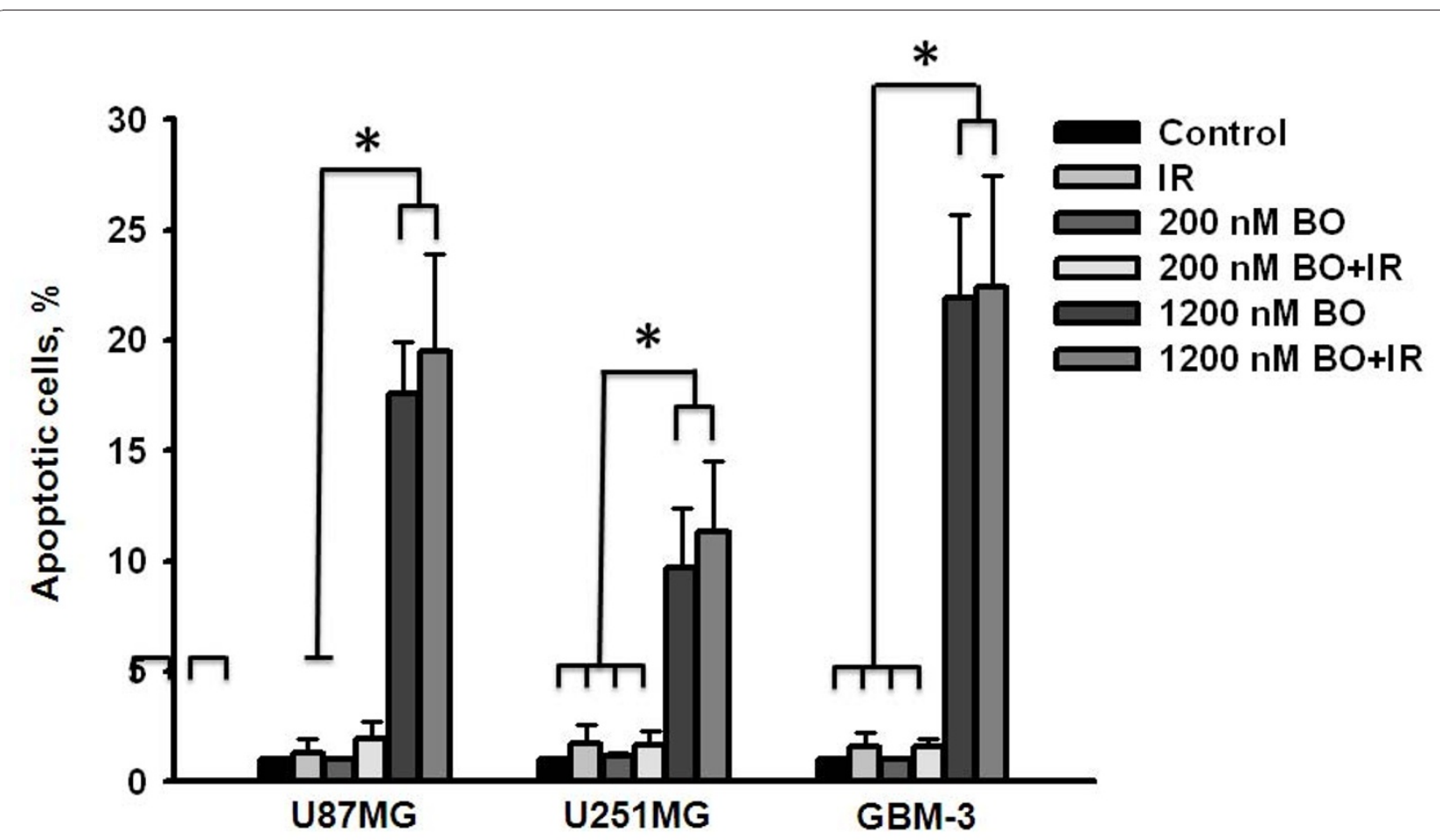

Figure 4 Apoptotic effects of BO-1051 in combination with irradiation in glioma cells. U87MG, U251MG and GBM-3 were exposed to 200 nM or higher concentration (1200 nM) of BO-1051 for 24 h and irradiated with 2 Gy, followed by FACS analysis of Annexin V-FITC and PI staining $24 \mathrm{~h}$ later. Control: no treatment; IR: ionizing radiation at $2 \mathrm{~Gy}$; BO: BO-1051; BO+IR: cells exposed to BO-1051 for $24 \mathrm{~h}$ and then irradiation with 2 Gy of $\gamma$-ray. Values are the means \pm SD of 3 independent experiments. ${ }^{*} p<0.05$.

was used. Mice bearing s.c. xenografts $\left(\sim 150 \mathrm{~mm}^{3}\right)$ were stratified by size and randomized into 4 groups: control, BO-1051 alone, irradiation alone (4 Gy), or combined BO-1051 plus radiation. For the BO-1051 treatments, mice were i.p. injected with dosage at $50 \mathrm{mg} / \mathrm{kg}$ on days 0,3 and 6 . The growth rates for the GBM-3 tumors exposed to each treatment are shown in Figure 6A. For each group, the time for tumors to grow from 150 to $1500 \mathrm{~mm}^{3}$ (i.e., a 10 -fold increase in tumor size) was calculated using tumor volumes from the individual mice in each group (mean $+\mathrm{SD}$ ). The time required for tumors to reach 10-times the starting volume increased from 20.2 days for control mice to 29.5 days for BO1051-treated mice. Irradiation treatment alone increased the time to reach 10-times the initial volume to 23.6 days. However, in mice that received the combination therapy, the time for tumors to reach 10-times the initial volume increased to 36.2 days, which is significantly greater than the individual treatment groups (Figure 6A; Table 2, $\mathrm{p}>0.05$ ). Thus, the growth delay after the combined treatment was more than the sum of the growth delays caused by either BO-1051 or radiation alone. To calculate an SER comparing the tumor radiation responses in mice with and without the BO-1051 treatment, the normalized tumor growth delay was measured to determine the role of BO-1051 on tumor growth delay induced by the combination treatment. The SER of the xenograft gliomas was 1.97 with versus without the combined treatment of BO-1051 and irradiation (Table 2). Thus, BO-1051 alone slows tumor growth and enhances the effect of radiation, which is similar to the results obtained in vitro. Finally, the Kaplan-Meier survival curves of the combined treated mice revealed a trend toward longer survival in mice (Figure. 6B). We also noticed that the maximal toxicity of these agents decreased with body weight, and there was no more than a $15 \%$ weight reduction compared to the pretreatment body weight. However after cession of treatment, the body weight recovered (data not shown).

\section{Discussion}

Although human GBM is one of the most radio-resistant tumors, radiotherapy remains routinely applied for patient treatment. Lots of efforts are made to develop methods for enhancing the radiosensitivity of GBM for promising therapy. Previous studies have shown that temozolomide (TMZ) combined with radiation exposure results in an increase of survival rate in a subset of human tumors $[3,25,26]$. Clinical studies also indicate that delivery of TMZ during radiotherapy increases 


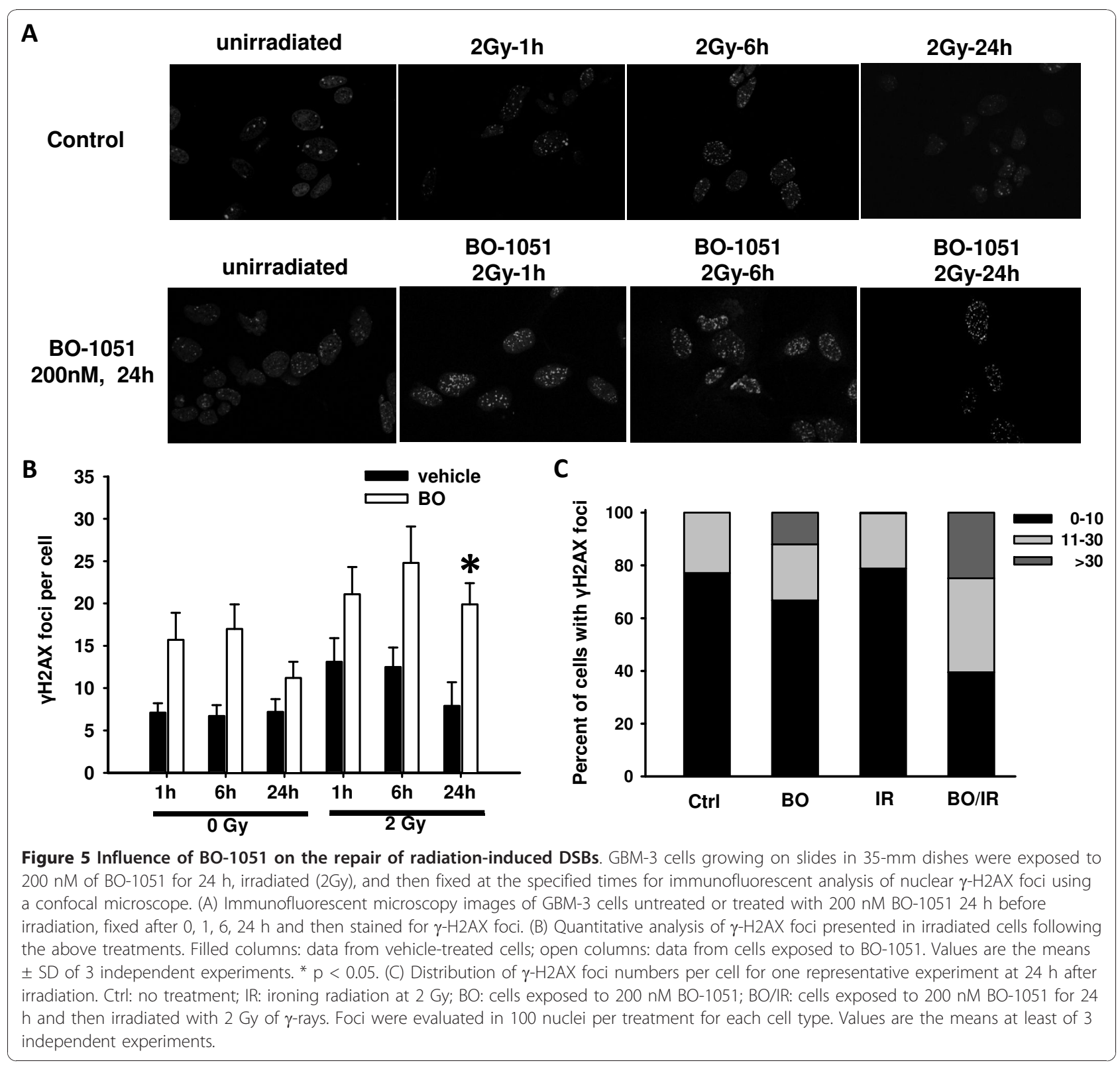

survival rates of GBM patients, which suggests that this DNA alkylating agent can enhance the radiosensitivity of GBM $[2,27,28]$. Based on these previous studies, more efficient and safe DNA alkylating agents should be developed to increase the radiosensitivity in human GBM. Use of BO-1051 for cancer treatment has been supported by in vitro and in vivo preclinical studies $[3,26]$. The data presented here showed that the treatment of primary glioma cells and established cell lines with BO-1051 resulted in a dose-dependent induction of clonogenic cell death. It is supposed that BO-1051 can enhance the radiosensitivity via a synergistic effect since the survival fractions of combined treatment are lower than that of each individual treatment on glioma cell.
However, additional studies are required to confirm that BO-1051 plays a synergistic or additive role on radiotherapy of gliomas. The anti-tumor and radiosensitizing effects of BO-1051 are encouraging because drugs showing efficacy against malignant glioma are still uncommon.

Bifunctional $\mathrm{N}$-mustard alkylating agents, such as BO1051, exhibits anticancer activity due to its ability to produce DNA interstrand and/or intrastrand cross-links $[29,30]$. As has been known, bifunctional alkylating agents induce collapsed replication forks that can lead to either cell cycle arrest, DNA repair, or apoptosis [31]. For example, the new synthesized alkylating agent BO-1012 shows anticancer activity on xenograft tumors 


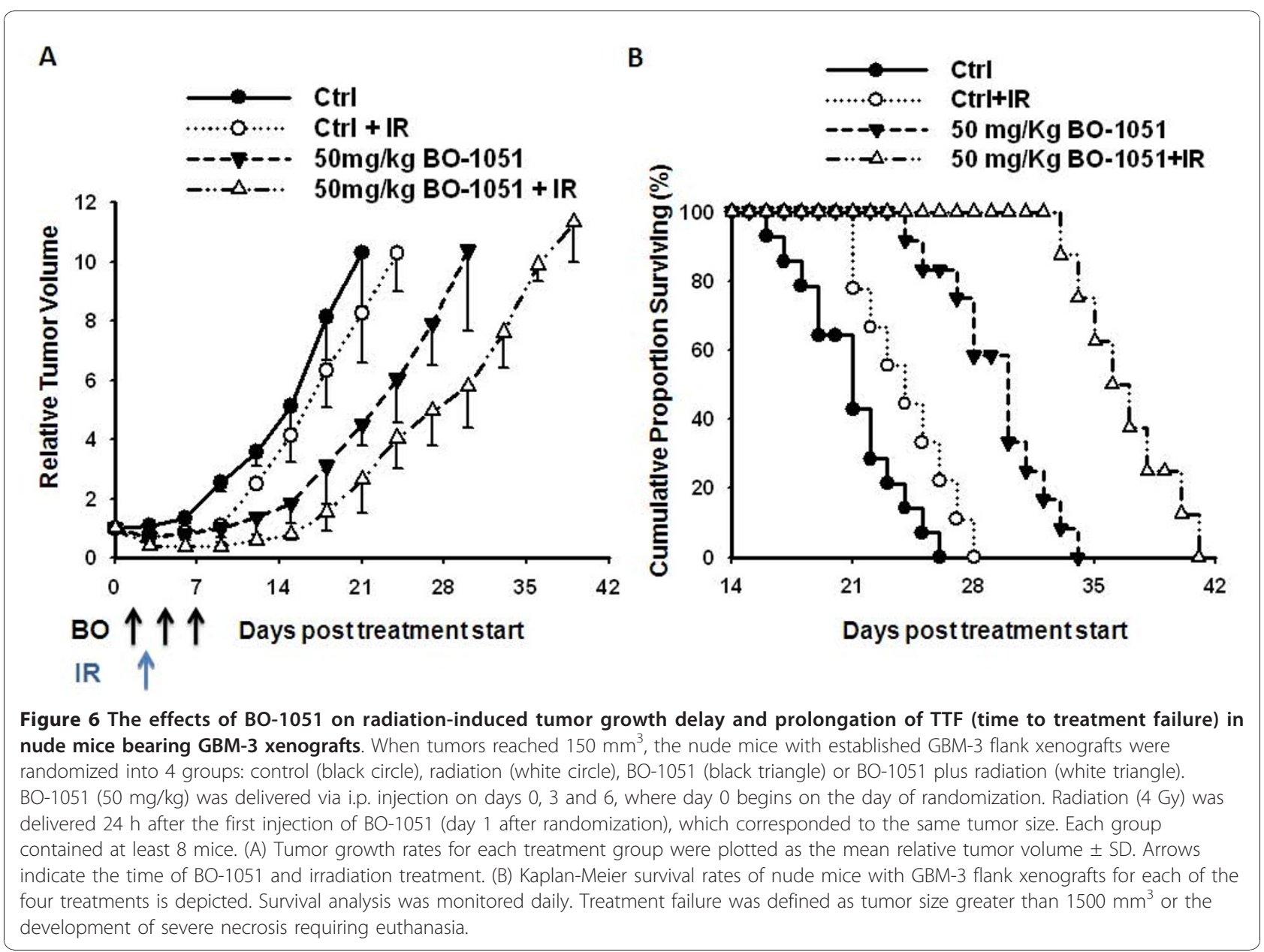

that are formed by various human lung and bladder cancer cells [32]. BO-1051 and its analog(s) also exhibit similar behavior, and several related synthetic bifunctional N-mustards are under development [33]. Because BO-1051 contains the inherent lipophilicity for penetration through blood-brain barrier, it has efficiently demonstrated the ability to inhibit the growth of xenograft glioma in nude mice. Compared to other clinically used alkylating agents, such as melphalan and cisplatin, BO-1051 induced a higher level of ICLs [14]. BO-1051 also enhances the radiosensitivity of human glioma cell lines.

Although repair mechanisms such as homologous recombination and nonhomologous end-joining are important mammalian responses to double-strand DNA damage, cell cycle regulation is perhaps the most important determinant of irradiation sensitivity [22,34]. The cell cycle is strongly affected by DNA damage, and a cell's radiosensitivity depends on cell cycle position and progression [22]. Conventionally, the $G_{2} / M$ phase is the

Table 2 BO-1051-induced tumor growth delay in GBM-3 xenografts

\begin{tabular}{|c|c|c|c|c|}
\hline Treatment group & Tumor growth period, days* & Absolute growth delayt & Normalized growth delay & Enhancement ratio\# \\
\hline Control & 20.2 & & & \\
\hline BO-1051 & 29.5 & 9.3 & & \\
\hline IR & 23.6 & 3.4 & & \\
\hline $\mathrm{BO}-1051+\mathrm{IR}$ & 36.2 & 16 & 6.7 & 1.97 \\
\hline
\end{tabular}

* Time for subcutaneous tumors to grow from the initial tumor volume to 10 times (see text).

† The number of days for the treated tumors to reach 10 times the initial tumor volume minus the number of days for the control group to reach the same size. \# The number of days for the tumors in the BO-1051+IR group to reach 10 times the initial tumor volume minus the number of days for tumors in the BO-1051only group to reach the same size.

\# Normalized growth delay for the BO-1051+IR group divided by absolute growth delay for the radiation-only group. 
most radiosensitive phase compared to others. Several chemotherapeutic agents have been reported to enhance the radiosensitivity of cancer cells by accumulating the $\mathrm{G}_{2} / \mathrm{M}$ population, such as paclitaxel, indomethacin, 2-methoxyestradiol and TMZ [3,22,25,35-37]. From the results in this study, BO-1051 works by partially synchronized glioma cells in the most radiosensitive phase of the cell cycle, and it is suggested that BO-1051 may be a useful agent for adjuvant therapy on the glioma.

The phosphatidyl-inositol kinase-related protein ATM (ataxia-telangiectasia mutated), the most proximal signal transducer initiating cell cycle changes after the DNA damage/genomic stress [38], can be activated by BO-1051 in a dose-dependent manner in SAS cell line. It also activates the checkpoint kinase 2 (Chk2) in squamous cell carcinoma cell line after exposure to BO-1051 (unpublished observation). Chk2 activity is necessary for the phosphorylation of the dual-specificity phosphatases Cdc25A/C, which inactivates the enzymes, blocks CDK1 activation and causes a $G_{2}$ arrest [39]. Furthermore, ATM's essential role in DNA damage and repair is highlighted by the extreme sensitivity to ionizing radiation of cells with defective ATM $[40,41]$. It, together with DNA-dependent protein kinase, phosphorylate the histone $\gamma-\mathrm{H} 2 \mathrm{AX}$ foci, which can be visualized by immunofluorescence microscope as a discrete nuclear foci reflecting sites of DNA DSBs $[42,43]$. Although the specific relationship between the appearance of $\gamma-\mathrm{H} 2 \mathrm{AX}$ foci and the repair of DSBs has not been completely defined, the reduction in the number of $\gamma-\mathrm{H} 2 \mathrm{AX}$ foci in irradiated cells correlates with DNA repair, which is associated with the radiosensitivity [44-46]. It is also known that $\gamma-\mathrm{H} 2 \mathrm{AX}$ is present in focal aggregates at sites of double-strand DNA damage and complex with other important repair molecules. $\gamma-\mathrm{H} 2 \mathrm{AX}$ is required for foci formation for numerous factors including p53, MRN complex (MRE-11, RAD50, and NBS1), and BRCA1 [47]. MRN complex has also been implicated in the repair of small fraction of DSBs detectable as $\gamma-\mathrm{H} 2 \mathrm{AX}$ foci that remain $24 \mathrm{~h}$ post-irradiation [48] Therefore, the observation that combined BO-1051 plus radiation significantly increased the levels of $\gamma$-H2AX foci. Because the prolonged expression of radiation-induced $\gamma-\mathrm{H} 2 \mathrm{AX}$ foci may reflect the end result of disparate processes and events leading to maintenance of unrepaired DSBs, a distinctly different mechanism may be involved. Whereas the mechanism of this repair inhibition is not revealed in this investigation, additional investigations are required to define the molecular processes responsible for BO-1051mediated radiosensitization.

Radiation sensitization could occur through any one of multiple modes of cell death. Zou et al. observed radiosensitization through the promotion of apoptosis [35], while another research group reported radiosensitization through a mitotic catastrophe $[26,49]$ or senescence [50].
However, theses phenomenon were not detected in glioma cells exposed to BO-1051 following irradiation. Recently, we found that BO-1051 can induce autophagy in glioma cell lines (unpublished observation), and several lines of evidence have supported that autophagy is one of the causes of radiosensitization instead of apoptosis [51-53]. Therefore, the correlation between autophagy and radiosensitivity needs to be further investigated.

Given that human GBM usually exhibits high radioresistance, it is necessary to search for a specific radiosensitizer to enhance the radiosensitivity of GBM during radiotherapy. Kil et al. have demonstrated that TMZ may be used as a radiosensitizer because it can enhance the radiosensitivity of U251MG cells formed xenograft tumors [26]. Nevertheless, we found that TMZ was neither able to increase the radiosensitivity of xenograft tumors derived from GBM-3 cells nor able to delay tumor growth and improve animal survival after treatment (unpublished observation). Therefore, TMZ may exhibit cell specific effects for the treatment of different sources of human GBM. However, BO-1051 enhances the radiosensitivity of various glioma cell lines, as well as that of the corresponding xenograft tumors formed by GBM-3 cells. These results suggest that BO-1051 is a radiosensitizer with broader effects on different human GBM, and it may possess a clinical potential in the therapeutic strategy for treating malignant gliomas.

\section{Conclusions}

GBM is the most malignant primary brain tumor in adults, but the effective therapeutic strategies remain under investigation. BO-1051 has been shown to inhibit the growth of gliomas. Here we further demonstrate that BO-1051 can significantly enhance the radiosensitivity. The enhanced radiosensitivity was found to be associated with $G_{2} / M$ phase arrest as well as the sustained DNA damage. In vivo studies further demonstrated that BO-1051 enhanced the radiotherapeutic effects on GBM-3-beared xenograft tumors. In this model, the combination of $\mathrm{BO}-1051$ plus radiation produced the best response in terms of both local control and survival. These data suggest that BO-1051 provides a new strategy to improve therapeutic gain for radiation therapy.

\section{Abbreviations}

BO-1051: 1-\{4-[Bis(2-chloroethyl)amino]phenyl\}-3-[2-methyl-5-(4-methylacridin9-ylamino)phenyl]urea; DBSs: Double-strand breaks; GBM: Glioblastoma multiforme; ICLs: Interstrand cross-linking; PE: Plating efficacy; SER: Sensitizer enhancement ratio; SF: Surviving fraction; TMZ: Temozolomide; TTF: Time to treatment failure.

\section{Acknowledgements}

This study was supported by research grants from National Science Council(NSC 97-3111-B-075-001-MY3, NSC99-2811-B-016-007-MY3, 98-2320-B-075-003MY3), Taipei Veterans General Hospital (V97B1-006, E1-008, F-001), Tri-Service 
General Hospital (TSGH-C100-047), the Joint Projects of UTVGH (VGHUST 98-p101), Yen-Tjing-Ling Medical Foundation (96/97/98), National Yang-Ming University (Ministry of Education, Aim for the Top University Plan) \& Genomic Center Project, Institute of Biological medicine, Academia Sinica (IBMS-CRC99p01), and Center of Excellence for Cancer Research at Taipei Veterans General Hospital (DOH99-TD-C-111-007), Taiwan.

\section{Author details}

'Graduate Institutes of Life Sciences, National Defense Medical Center \& Department of Neurological Surgery, Tri-Service General Hospital, Taipei, Taiwan. ${ }^{2}$ Department of Medical Research and Education, Taipei Veterans General Hospital, Taipei, Taiwan. ${ }^{3}$ Institute of Pharmacology, National YangMing University, Taipei, Taiwan. ${ }^{4}$ Institute of Clinical Medicine, School of Medicine, National Yang-Ming University, Taipei, Taiwan. ${ }^{5}$ Institute of Biomedical Sciences, Academia Sinica, Taipei, Taiwan. ${ }^{6}$ Department of Biomedical Image and Radiological Sciences, School of Biomedical Science and Engineering, National Yang-Ming University, Taipei, Taiwan. ${ }^{7}$ Cancer Center, Taipei Veterans General Hospital, Taipei, Taiwan. ${ }^{8}$ Department of Neurosurgery, Neurological Institute, Taipei Veterans General Hospital, Taipei, Taiwan.

\section{Authors' contributions}

PMC carried out most of the study, participated in its design, and drafted the manuscript. LHC, MTC, MHC, and YHS did parts of the statistical analysis and helped in discussion of data. YWC, SHY, PHT involved in drafting the manuscript in the section of radiotherapy techniques. HIM, SHC, TLS and YJL jointly conceived of the study, and coordination, participated in its design and drafted the manuscript. All authors read and approved the manuscript.

\section{Competing interests}

The authors declare that they have no competing interest.

Received: 1 September 2010 Accepted: 19 January 2011

Published: 19 January 2011

\section{References}

1. Walker MD, Green SB, Byar DP, Alexander E Jr, Batzdorf U, Brooks WH, Hunt WE, MacCarty CS, Mahaley MS Jr, Mealey J Jr, et al: Randomized comparisons of radiotherapy and nitrosoureas for the treatment of malignant glioma after surgery. N Engl J Med 1980, 303(23):1323-1329.

2. Stupp R, Dietrich PY, Ostermann Kraljevic S, Pica A, Maillard I, Maeder P, Meuli R, Janzer R, Pizzolato G, Miralbell R, et al: Promising survival for patients with newly diagnosed glioblastoma multiforme treated with concomitant radiation plus temozolomide followed by adjuvant temozolomide. J Clin Oncol 2002, 20(5):1375-1382.

3. Stupp R, Mason WP, van den Bent MJ, Weller M, Fisher B, Taphoorn MJ, Belanger K, Brandes AA, Marosi C, Bogdahn U, et al: Radiotherapy plus concomitant and adjuvant temozolomide for glioblastoma. N Engl J Med 2005, 352(10):987-996.

4. Wadhwa PD, Zielske SP, Roth JC, Ballas CB, Bowman JE, Gerson SL: Cancer gene therapy: scientific basis. Annu Rev Med 2002, 53:437-452.

5. Grando SA, Kawashima K, Wessler I: Introduction: the non-neuronal cholinergic system in humans. Life Sci 2003, 72(18-19):2009-2012.

6. Maze R, Carney JP, Kelley MR, Glassner BJ, Williams DA, Samson L: Increasing DNA repair methyltransferase levels via bone marrow stem cell transduction rescues mice from the toxic effects of 1,3-bis(2chloroethyl)-1-nitrosourea, a chemotherapeutic alkylating agent. Proc Natl Acad Sci USA 1996, 93(1):206-210.

7. Gravatt GL, Baguley BC, Wilson WR, Denny WA: DNA-directed alkylating agents. 6. Synthesis and antitumor activity of DNA minor groovetargeted aniline mustard analogues of pibenzimol (Hoechst 33258). J Med Chem 1994, 37(25):4338-4345.

8. Gourdie TA, Valu KK, Gravatt GL, Boritzki TJ, Baguley BC, Wakelin LP, Wilson WR, Woodgate PD, Denny WA: DNA-directed alkylating agents. 1. Structure-activity relationships for acridine-linked aniline mustards: consequences of varying the reactivity of the mustard. J Med Chem 1990, 33(4):1177-1186.

9. Bacherikov VA, Chou TC, Dong HJ, Zhang X, Chen CH, Lin YW, Tsai TJ, Lee RZ, Liu LF, Su TL: Potent antitumor 9-anilinoacridines bearing an alkylating $\mathrm{N}$-mustard residue on the anilino ring: synthesis and biological activity. Bioorg Med Chem 2005, 13(12):3993-4006.
10. Su TL, Lin YW, Chou TC, Zhang X, Bacherikov VA, Chen CH, Liu LF, Tsai TJ: Potent antitumor 9-anilinoacridines and acridines bearing an alkylating $\mathrm{N}$-mustard residue on the acridine chromophore: synthesis and biological activity. J Med Chem 2006, 49(12):3710-3718.

11. Su TL: Development of DNA topoisomerase II-mediated anticancer agents, 3-(9-acridinylamino)-5-hydroxymethylanilines (AHMAs) and related compounds. Curr Med Chem 2002, 9(18):1677-1688.

12. Lee CH, Chou TC, SU TL, Yu J, Shao LE, Yu AL: BO-0742, a derivative of AHMA and N-mustard, has selective toxicity to drug sensitive and drug resistant leukemia cells and solid tumors. Cancer Lett 2009, 276(2):204-211.

13. Kapuriya N, Kapuriya K, Dong H, Zhang X, Chou TC, Chen YT, Lee TC, Lee WC, Tsai TH, Naliapara Y, et al: Novel DNA-directed alkylating agents: design, synthesis and potent antitumor effect of phenyl N-mustard-9anilinoacridine conjugates via a carbamate or carbonate linker. Bioorg Med Chem 2009, 17(3):1264-1275.

14. Kapuriya N, Kapuriya K, Zhang X, Chou TC, Kakadiya R, Wu YT, Tsai TH, Chen YT, Lee TC, Shah A, et al: Synthesis and biological activity of stable and potent antitumor agents, aniline nitrogen mustards linked to 9-anilinoacridines via a urea linkage. Bioorg Med Chem 2008, 16(10):5413-5423.

15. Kim JH, Shin JH, Kim IH: Susceptibility and radiosensitization of human glioblastoma cells to trichostatin $A$, a histone deacetylase inhibitor. Int J Radiat Oncol Biol Phys 2004, 59(4):1174-1180.

16. Camphausen K, Brady KJ, Burgan WE, Cerra MA, Russell JS, Bull EE, Tofilon PJ: Flavopiridol enhances human tumor cell radiosensitivity and prolongs expression of gammaH2AX foci. Mol Cancer Ther 2004, 3(4):409-416.

17. McCord AM, Jamal M, Williams ES, Camphausen K, Tofilon PJ: CD133+ glioblastoma stem-like cells are radiosensitive with a defective DNA damage response compared with established cell lines. Clin Cancer Res 2009, 15(16):5145-5153.

18. Dote H, Cerna D, Burgan WE, Carter DJ, Cerra MA, Hollingshead MG Camphausen K, Tofilon PJ: Enhancement of in vitro and in vivo tumor cell radiosensitivity by the DNA methylation inhibitor zebularine. Clin Cancer Res 2005, 11(12):4571-4579.

19. Barker CA, Burgan WE, Carter DJ, Cerna D, Gius D, Hollingshead MG, Camphausen K, Tofilon PJ: In vitro and in vivo radiosensitization induced by the ribonucleotide reductase inhibitor Triapine (3-aminopyridine-2carboxaldehyde-thiosemicarbazone). Clin Cancer Res 2006, 12(9):2912-2918.

20. Russell JS, Burgan W, Oswald KA, Camphausen K, Tofilon PJ: Enhanced cell killing induced by the combination of radiation and the heat shock protein 90 inhibitor 17-allylamino-17- demethoxygeldanamycin: a multitarget approach to radiosensitization. Clin Cancer Res 2003, 9(10 Pt 1):3749-3755.

21. Geldof AA, Slotman BJ: Radiosensitizing effect of cisplatin in prostate cancer cell lines. Cancer Lett 1996, 101(2):233-239.

22. Pawlik TM, Keyomarsi $K$ : Role of cell cycle in mediating sensitivity to radiotherapy. Int J Radiat Oncol Biol Phys 2004, 59(4):928-942.

23. Sinclair WK, Morton RA: X-ray sensitivity during the cell generation cycle of cultured Chinese hamster cells. Radiat Res 1966, 29(3):450-474.

24. Pilch DR, Sedelnikova OA, Redon C, Celeste A, Nussenzweig A, Bonner WM: Characteristics of gamma-H2AX foci at DNA double-strand breaks sites. Biochem Cell Biol 2003, 81(3):123-129.

25. Chakravarti A, Erkkinen MG, Nestler U, Stupp R, Mehta M, Aldape K, Gilbert MR, Black PM, Loeffler JS: Temozolomide-mediated radiation enhancement in glioblastoma: a report on underlying mechanisms. Clin Cancer Res 2006, 12(15):4738-4746.

26. Kil WJ, Cerna D, Burgan WE, Beam K, Carter D, Steeg PS, Tofilon PJ, Camphausen $\mathrm{K}:$ In vitro and in vivo radiosensitization induced by the DNA methylating agent temozolomide. Clin Cancer Res 2008, 14(3):931-938.

27. Kanzawa T, Germano IM, Komata T, Ito H, Kondo Y, Kondo S: Role of autophagy in temozolomide-induced cytotoxicity for malignant glioma cells. Cell Death Differ 2004, 11(4):448-457.

28. Yung WK, Albright RE, Olson J, Fredericks R, Fink K, Prados MD, Brada M, Spence A, Hohl RJ, Shapiro W, et al: A phase II study of temozolomide vs. procarbazine in patients with glioblastoma multiforme at first relapse. $\mathrm{Br}$ J Cancer 2000, 83(5):588-593.

29. Tomasz M, Palom Y: The mitomycin bioreductive antitumor agents: crosslinking and alkylation of DNA as the molecular basis of their activity. Pharmacol Ther 1997, 76(1-3):73-87. 
30. Panasci $L, X u Z Y$, Bello V, Aloyz R: The role of DNA repair in nitrogen mustard drug resistance. Anticancer Drugs 2002, 13(3):211-220.

31. Sorensen CS, Hansen LT, Dziegielewski J, Syljuasen RG, Lundin C, Bartek J, Helleday T: The cell-cycle checkpoint kinase Chk1 is required for mammalian homologous recombination repair. Nat Cell Biol 2005, 7(2):195-201.

32. Kakadiya R, Dong H, Lee PC, Kapuriya N, Zhang X, Chou TC, Lee TC, Kapuriya K, Shah A, Su TL: Potent antitumor bifunctional DNA alkylating agents, synthesis and biological activities of 3a-aza-cyclopenta[a] indenes. Bioorg Med Chem 2009, 17(15):5614-5626.

33. Kakadiya R, Dong H, Kumar A, Narsinh D, Zhang X, Chou TC, Lee TC, Shah A, Su TL: Potent DNA-directed alkylating agents: Synthesis and biological activity of phenyl $\mathrm{N}$-mustard-quinoline conjugates having a urea or hydrazinecarboxamide linker. Bioorg Med Chem 2010, 18(6):2285-2299.

34. Shrivastav M, De Haro LP, Nickoloff JA: Regulation of DNA double-strand break repair pathway choice. Cell Res 2008, 18(1):134-147.

35. Zou H, Zhao S, Zhang J, Lv G, Zhang X, Yu H, Wang H, Wang L: Enhanced radiation-induced cytotoxic effect by $2-\mathrm{ME}$ in glioma cells is mediated by induction of cell cycle arrest and DNA damage via activation of ATM pathways. Brain Res 2007, 1185:231-238.

36. Jin C, Wu H, Liu J, Bai L, Guo G: The effect of paclitaxel-loaded nanoparticles with radiation on hypoxic MCF-7 cells. J Clin Pharm Ther 2007, 32(1):41-47.

37. Furuta $Y$, Hunter $N$, Barkley $T J r$, Hall E, Milas L: Increase in radioresponse of murine tumors by treatment with indomethacin. Cancer Res 1988, 48(11):3008-3013.

38. Samuel T, Weber HO, Funk JO: Linking DNA damage to cell cycle checkpoints. Cell Cycle 2002, 1(3):162-168.

39. Herzinger T, Funk JO, Hillmer K, Eick D, Wolf DA, Kind P: Ultraviolet B irradiation-induced $\mathrm{G} 2$ cell cycle arrest in human keratinocytes by inhibitory phosphorylation of the cdc2 cell cycle kinase. Oncogene 1995, 11(10):2151-2156.

40. Kastan MB, Lim DS: The many substrates and functions of ATM. Nat Rev Mol Cell Biol 2000, 1(3):179-186.

41. Collis SJ, Swartz MJ, Nelson WG, DeWeese TL: Enhanced radiation and chemotherapy-mediated cell killing of human cancer cells by small inhibitory RNA silencing of DNA repair factors. Cancer Res 2003, 63(7):1550-1554

42. Rogakou EP, Pilch DR, Orr AH, Ivanova VS, Bonner WM: DNA doublestranded breaks induce histone H2AX phosphorylation on serine 139. J Biol Chem 1998, 273(10):5858-5868.

43. Sedelnikova OA, Rogakou EP, Panyutin IG, Bonner WM: Quantitative detection of (125)IdU-induced DNA double-strand breaks with gammaH2AX antibody. Radiat Res 2002, 158(4):486-492.

44. Olive PL, Banath JP: Phosphorylation of histone $H 2 A X$ as a measure of radiosensitivity. Int J Radiat Oncol Biol Phys 2004, 58(2):331-335.

45. Nazarov IB, Smirnova AN, Krutilina RI, Svetlova MP, Solovjeva LV, Nikiforov AA, Oei SL, Zalenskaya IA, Yau PM, Bradbury EM, et al: Dephosphorylation of histone gamma-H2AX during repair of DNA double-strand breaks in mammalian cells and its inhibition by calyculin A. Radiat Res 2003, 160(3):309-317.

46. Banath JP, Macphail SH, Olive PL: Radiation sensitivity, H2AX phosphorylation, and kinetics of repair of DNA strand breaks in irradiated cervical cancer cell lines. Cancer Res 2004, 64(19):7144-7149.

47. Bilsland E, Downs JA: Tails of histones in DNA double-strand break repair. Mutagenesis 2005, 20(3):153-163.

48. Lobrich M, Jeggo PA: Harmonising the response to DSBs: a new string in the ATM bow. DNA Repair (Amst) 2005, 4(7):749-759.

49. Mitchell JB, Choudhuri R, Fabre K, Sowers AL, Citrin D, Zabludoff SD, Cook JA: In vitro and in vivo radiation sensitization of human tumor cells by a novel checkpoint kinase inhibitor, AZD7762. Clin Cancer Res 2010, 16(7):2076-2084

50. Lehmann BD, McCubrey JA, Terrian DM: Radiosensitization of Prostate Cancer by Priming the Wild-Type p53-Dependent Cellular Senescence Pathway. Cancer Biol Ther 2007, 6(8):1165-1170.

51. Fujiwara K, Iwado E, Mills GB, Sawaya R, Kondo S, Kondo Y: Akt inhibitor shows anticancer and radiosensitizing effects in malignant glioma cells by inducing autophagy. Int J Oncol 2007, 31(4):753-760.

52. Kim KW, Hwang M, Moretti L, Jaboin JJ, Cha YI, Lu B: Autophagy upregulation by inhibitors of caspase- 3 and mTOR enhances radiotherapy in a mouse model of lung cancer. Autophagy 2008, 4(5):659-668

53. Tsuboi $Y$, Kurimoto M, Nagai S, Hayakawa $Y$, Kamiyama H, Hayashi N, Kitajima I, Endo S: Induction of autophagic cell death and radiosensitization by the pharmacological inhibition of nuclear factorkappa B activation in human glioma cell lines. J Neurosurg 2009, 110(3):594-604.

doi:10.1186/1748-717X-6-7

Cite this article as: Chu et al:: Enhancement of radiosensitivity in human glioblastoma cells by the DNA N-mustard alkylating agent BO-1051 through augmented and sustained DNA damage response. Radiation Oncology 2011 6:7.

\section{Submit your next manuscript to BioMed Central and take full advantage of:}

- Convenient online submission

- Thorough peer review

- No space constraints or color figure charges

- Immediate publication on acceptance

- Inclusion in PubMed, CAS, Scopus and Google Scholar

- Research which is freely available for redistribution

Submit your manuscript at www.biomedcentral.com/submit
C Biomed Central 